\title{
Prosedur Pengambilalihan Obyek Jaminan Hak Tanggungan dalam Masalah Kredit Macet
}

\author{
Triamy Rostarum ${ }^{1}$ \\ Fakultas Hukum Universitas Batanghari \\ Jalan Slamet Riyadi, Broni, Kota Jambi (0741) 65351 \\ triamyrostarum@gmail.com
}

\begin{abstract}
Abstrak
Penelitian ini bertujuan untuk mengetahui kapan obyek jaminan hak tanggungan milik debitur yang mengalami kredit macet dapat diambil aliholeh PT. Bank mandiri (Persero) Tbk Cabang Jambi, dan mengetahui peran Pejabat Pembuat Akta Tanah (PPAT) dalam pembuatan akta terhadap jaminan yang diambil alih oleh PT. Bank mandiri (Persero) Tbk Cabang Jambi. Metode penelitian yang digunakan adalah yuridis empiris. Hasil penelitian yaitu setelah dilakukan eksekusi jaminan hak tanggungan melalui pelelangan dan jaminan tidak laku terjual maka barulah PT. Bank mandiri (Persero) Tbk Cabang Jambi dapat melakukan pengambil alihan jaminan Hak Tanggungan atau dikenal sebagai AYDA melalui pelelangan dengan menandatangani kesepakatan pengambil alih angunan antara bank dengan debitur atau membuat berita acara penyelesaian kredit secara notariil. Peran PPAT yaitu membuat Akta Jual Beli (AJB) yang merupakan alas hak yang sah terhadap beralihnya hak atas tanah dalam pengambil alihan obyek jaminan Hak Tanggungan.
\end{abstract}

Kata Kunci: Kredit Macet, Agunan Yang Diambil Alih (AYDA)

\begin{abstract}
This research aims to find out that the objects of collateral that have experienced credit or credit can be taken over by PT. Bank Mandiri (Persero) Tbk Branch of Jambi, and knowing the movement of Land Officials (PPAT) in the making of guarantees taken over by PT. Bank Mandiri (Persero) Tbk Jambi Branch. The research method used was disciplinary. The results of the research were done after the execution of the insurance coverage through auction and not to sell the news to PT. Bank Mandiri (Persero) Tbk Jambi branch can carry out the takeover of insurance coverage or as an ODA through auction by signing the takeover agreement between the bank and the facility or making news about the settlement of the February 2016 debt. The role of the PPAT is to create a Sales Act (AJB) which is the legal basis for the right to transfer land rights in the takeover of insurance benefits.
\end{abstract}

Keywords: CreditMetet, Collateral Taken Alone (AYDA)

\section{PENDAHULUAN}

Kredit yang baik adalah kredit yang diberikan sesuai dengan kebutuhan riil debitur, sehingga dapat memperbaiki/meningkatkan kinerja usaha debitur dan kredit dapat dikembalikan kepada bank dengan tepat waktu dan menguntungkan bank. Pemberian fasilitas kredit mengandung risiko sehingga bank dalam memberikan fasilitas kredit wajib mempunyai keyakinan berdasarkan analisis yang mendalam atas itikad dan kemampuan serta kesanggupan debitur untuk melunasi utangnya sesuai yang diperjanjikan seperti yang diatur dalam penjelasan Pasal 8 ayat (1) Undang-Undang Nomor 7 Tahun 1992 jo Undang-Undang Nomor 10 Tahun 1998 tentang Perbankan.

Risiko ialah kewajiban memikul kerugian yang disebabkan karena suatu kejadian di luar kesalahan salah satu pihak. ${ }^{2}$ Persoalan tentang risiko itu berpokok-pangkal pada terjadinya suatu peristiwa diluar kesalahan salah satu pihak. Peristiwa semacam itu dalam hukum perjanjian dengan suatu istilah hukum dinamakan "keadaan memaksa" ("overmacht", "force majeur"), dengan demikian persoalan tentang risiko itu merupakan buntut dari persoalan tentang keadaan memaksa, suatu kejadian yang tak disengaja dan tak dapat diduga. ${ }^{3}$ Berdasarkan uraian tentang pengertian risiko di atas tadi, persoalan risiko itu berpangkal pada terjadinya suatu peristiwa di luar kesalahan salah satu pihak yang mengadakan perjanjian, dengan kata lain

\footnotetext{
${ }^{1}$ Dosen Fakultas Hukum Universitas Batanghari Jambi

2 Subekti, Hukum Perjanjian, Intermasa, Jakarta, 2002, hlm 59

${ }^{3}$ Subekti, Aneka Perjanjian, PT. Citra Aditya Bakti, Bandung, 1995, hlm.25
} 
berpokok pangkal pada kejadian yang dalam hukum perjanjian dinamakan keadaan memaksa. Persoalan risiko adalah buntut dari suatu keadaan memaksa, sebagaimana ganti rugi adalah buntut dari wanprestasi.

Jaminan yang umumnya digunakan PT. Bank Mandiri (Persero) Tbk cabang Jambi adalah jaminan kebendaan yang salah satunya adalah tanah berikut segala sesuatu yang ada diatasnya, baik yang ada sekarang maupun yang akan ada di kemudian hari yang dijadikan jaminan. PT. Bank Mandiri (Persero) Tbk cabang Jambi harus melakukan tindakan untuk menguasai jaminan tersebut secara efektif, baik melalui pengikatan dan/atau pemblokiran rekening/dana dan/atau penguasan fisik jaminan. Undang-undang telah menentukan secara tegas bentuk pengikatan jaminan yang dilakukan atas benda tidak bergerak, untuk jaminan berupa tanah yang dapat diterima sebagai jaminan adalah tanah yang berstatus dan telah mempunyai Sertifikat Hak Milik, Hak Guna Bangunan, Hak Guna Usaha atau Hak Pakai Atas Tanah Negara (yang karena ketentuan perundang-undangan harus didaftar dan karena sifatnya dapat dipindahtangankan) dimana untuk tanah-tanah jenis ini pengikatannya dilakukan dengan Hak Tanggungan. Undang-Undang Nomor 4 Tahun 1996 tentang Hak Tanggungan atas tanah serta benda-benda yang berkaitan dengan tanah menjelaskan mengenai pengertian Hak Tanggungan yaituHak Tanggungan adalah hak jaminan atas tanah untuk pelunasan hutang tertentu, yang memberikan kedudukan diutamakan kepada kreditur tertentu terhadap kreditur-kreditur lain.

Jadi, Hak Tanggungan itu merupakan hak jaminan kebendaan terhadap hak atas tanah untuk pelunasan hutang tertentu, dengan memberikan kedudukan yang diutamakan kepada kreditur tertentu pemegang hak tanggungan terhadap kreditur lain. Jaminan yang diberikan kepada kreditur sebagai pemegang Hak Tanggungan adalah hak yang diutamakan atau mendahulu dari kreditur-kreditur lainnya bagi kreditur (Pemegang Hak Tanggungan). ${ }^{4}$

Eksekusi terhadap jaminan Hak Tanggungan merupakan langkah terakhir yang dilakukan kreditur selaku penerima Hak Tanggungan apabila debitur selaku pemberi Hak Tanggungan mengalami kredit macet. Salah satu ciri dan sifat lembaga hak jaminan atas tanah yang kuat, yaitu pelaksanaan eksekusi Hak Tanggungannya mudah dan pasti, bahwa pelaksanaan eksekusi Hak Tanggungan dilakukan melalui mekanisme yang sederhana tanpa melalui proses beracara di muka pengadilan. ${ }^{5}$

Pihak debitur seringkali melakukan penolakan atau keberatan saat jaminan atas namanya tersebut akan dieksekusi akibat debitur mengalami kredit macet sehingga bank selaku kreditur sering mengalami kendala dalam mengeksekusi benda jaminan untuk memenuhi pelunasan hutang debitur.Pasal 20 UUHT menjelaskan mengenai eksekusi Hak Tanggungan, yaitu apabila debitur cidera janji, maka menurut Pasal 6 UUHT, pemegang Hak Tanggungan pertama berhak untuk menjual obyek Hak Tanggungan atas kekuasaan sendiri melalui pelelangan umum serta mengambil pelunasan piutangnya dari hasil penjualan tersebut, atau eksekusi berdasarkan title eksekutorial. Sertifikat Hak Tanggungan yang merupakan tanda bukti adanya Hak Tanggungan yang diterbitkan oleh Kantor Pertanahan dan yang memuat irah-irah dengan kata-kata "DEMI KEADILAN BERDASARKAN KETUHANAN YANG MAHA ESA”, mempunyai kekuatan eksekutorial yang sama dengan putusan pengadilan yang telah memperoleh kekuatan hukum tetap dan berlaku sebagai pengganti grosse acte hypotheek sepanjang mengenai hak atas tanah, hal ini telah ditentukan dalam Pasal 14 ayat (1), (2), dan (3) UUHT, dengan demikian untuk melakukan eksekusi terhadap Hak Tanggungan yang telah dibebankan atas tanah dapat dilakukan tanpa harus melalui proses gugat-menggugat (proses litigasi) apabila debitur cidera janji. Berdasarkan ketentuan Pasal 20 ayat (2) UUHT atas kesepakatan pemberi dan pemegang Hak Tanggungan, penjualan obyek Hak Tanggungan dapat juga dilaksanakan melalui penjualan di bawah tangan jika dapat diperoleh harga tertinggi yang menguntungkan semua pihak.

Eksekusi secara di bawah tangan pelaksanaannya harus memenuhi beberapa persyaratan yang antara lain adanya kesepakatan antara pemberi Hak Tanggungan (debitur) dengan pemegang Hak Tanggungan (kreditur). Menurut Sutan Remi Sjahdeini dalam rangka penjualan di bawah tangan, masalah yang perlu dipecahkan adalah mengenai keabsahan penjualan obyek Hak Tanggungan oleh Bank, berdasarkan surat kuasa menjual di bawah tangan dari pemberi Hak Tanggungan, bagi kreditur dan debitur untuk menjual secara di bawah tangan adalah merupakan perkembangan baru sebagai bentuk eksekusi dalam UUHT untuk

\footnotetext{
${ }^{4}$ Rachmadi Usman, Hukum Jaminan Keperdataan, Sinar Grafika, Jakarta, 2008, hlm. 332

5 Ibid., hlm. 348
} 
perlindungan hukum bagi para pihak, sebab pada saat berlakunya hipotik atas tanah belum diatur secara jelas. Adapun bentuk eksekusi yang lain adalah parate executie. ${ }^{6}$

Parate executie menurut Subekti adalah menjalankan sendiri atau mengambil sendiri atau mengambil sendiri apa yang menjadi haknya, dalam arti tanpa perantara hakim, yang ditujukan atas sesuatu barang jaminan untuk selanjutnya menjual sendiri barang tersebut. ${ }^{7}$ Tartib berpendapat bahwa parate executie adalah eksekusi yang dilaksanakan sendiri oleh pemegang hak jaminan (gadai dan hipotik) tanpa melalui bantuan atau campur tangan Pengadilan Negeri,melainkan hanya berdasarkan bantuan Kantor Lelang Negara saja. ${ }^{8}$

PT. Bank Mandiri (Persero) Tbk Cabang Jambi telah melakukan ketiga upaya eksekusi tersebut terhadap jaminan milik debitur namun hasilnya nihil, maka Bank Mandiri telah membuat aturan Standar Prosedur Kredit yang didalamnya memuat ketentuan mengenai tindakan penyelamatan kredit dengan pengambilalihan aset debitur. Peraturan Bank Indonesia Nomor 14/15/PBI/2012 tentang Penilaian Kualitas Aset Bank Umum memuat ketentuan mengenai pengambilalihan aset debitur dalam ketentuan umum Pasal 1 ayat (15) yaitu mengenai Agunan Yang Diambil Alih (AYDA), peraturan Bank Mandiri mengenai Pedoman Pelaksanaan Kredit juga memuat ketentuan mengenai Agunan Yang Diambil Alih (AYDA), sehingga berdasarkan ketentuan di atas maka memungkinkan bahwa kreditur dapat memiliki jaminan milik debitur. Hal tersebut bertentangan dengan Pasal 12 UUHT yang menyebutkan bahwa janji yang memberikan kewenangan kepada pemegang Hak Tanggungan untuk memiliki obyek Hak Tanggungan apabila debitur cidera janji, maka batal demi hukum.

Berdasarkan latar belakang diatas, maka dirumuskan masalah sebagai berikut:

1. Kapan obyek jaminan Hak Tanggungan milik debitur yang mengalami kredit macet dapat diambilalih oleh PT. Bank Mandiri (Persero) Tbk Cabang Jambi?

2. Bagaimana peran Pejabat Pembuat Akta Tanah dalam pembuatan akta terhadap obyek jaminan yang diambilalih oleh PT. Bank Mandiri (Persero) Tbk Cabang Jambi?

\section{METODE PENELITIAN}

Penelitian ini menggunakan metode yuridis empiris, yaitu penelitian yang dilakukan untuk mendapatkan data primer yang berkenaan dengan hal-hal yang ada di lapangan dan didukung juga oleh penelitian kepustakaan untuk mendapatkan data sekunder. Penelitian kepustakaan diperoleh dari membaca dan mempelajari bahan-bahan bacaan yang berupa literatur dan penelitian-penelitian yang relevan, sedangkan penelitian lapangan melalui wawancara dengan narasumber dan responden.

\section{HASIL DAN PEMBAHASAN}

\section{Pengambilalihan Obyek Jaminan Hak Tanggungan Milik Debitur yang Mengalami Kredit Macet oleh PT. Bank Mandiri (Persero) Tbk Cabang Jambi}

Pemberian kredit oleh Bank mengandung risiko kegagalan atau kemacetan dalam pelunasannya. Bank harus meyakini bahwa kredit yang akan diberikannya tersebut dapat dilunasi kembali pada waktunya oleh nasabah debitur dan tidak akan berkembang menjadi kredit bermasalah atau kredit macet. Penelitian ini dilakukan dengan wawancara terhadap narasumber dan responden dari pihak PT. Bank Mandiri (Persero) Tbk Cabang Jambi yaitu Team Leader Credit Operation Floor, Relationship Manager Business Banking Center, Team Leader Business Banking Center, dan Notaris/ PPAT, serta Kepala Seksi Kepatuhan Internal KPKNL Jambi.

Bank Mandiri telah mengeluarkan berbagai peraturan perkreditan, namun risiko adanya kredit bermasalah maupun kredit macet tetap ada, seperti yang terjadi di Bank Mandiri Business Banking Center (BBC) cabang Jambi dimana kredit Nyonya S sebagai nasabah/debitur dikategorikan macet. ${ }^{9}$ Nyonya $\mathrm{S}$ mengajukan Kredit ke PT. Bank Mandiri (Persero) Tbk Cabang Jambi dengan limit kredit

\footnotetext{
${ }^{6}$ Herowati Poesoko, Parate Executie Obyek Hak Tanggungan, LaksBang PRESSindo, Yogyakarta, 2008, hlm 5

7 Ibid., hlm 5-6

${ }^{8}$ Ibid., hlm 6

${ }^{9}$ Berdasarkan hasil wawancara dengan Bapak Yudi Iswahyudi selaku Team Leader Business Banking Center (BBC) PT. Bank Mandiri (Persero) Tbk Cabang Jambi, tanggal 2 Desember 2013
} 
Rp.1.000.000.000,- (satu milyar rupiah) untuk tujuan tambahan modal kerja Nyonya S memberikan agunan berupa fixed asset yaitu dua bidang tanah bangunan yang telah ada atau akan ada dan dengan segala penambahan/ perubahannya di kemudian hari yang didirikan di atas Tanah

Nyonya $\mathrm{S}$ dalam proses berjalan mengalami kesulitan pembayaran agunan kredit sehingga kredit Nyonya S masuk kategori macet. Berdasarkan hasil wawancara dengan Bapak Yudi Iswahyudi, sebelum dinyatakan macet Bank Mandiri telah menyampaikan surat teguran kredit (SP 1, SP 2) kepada debitur Nyonya S, surat teguran diberikan sejak menurunnya kolektibilitas kredit dari lancar menjadi dalam perhatian khusus yang isinya telah terjadi tunggakan pokok dan/atau bunga kredit dengan permintaan untuk segera menyelesaikan tunggakan kewajiban tersebut. Bank Mandiri juga melakukan penagihan terhadap Nyonya S, namun demikian persyaratan minimal yang harus dipenuhi untuk berhasilnya pelaksanaan penagihan adalah bahwa debitur masih memiliki itikad baik, usahanya masih berjalan sehingga masih mampu memberikan penghasilan, masih memiliki persediaan/stock berupa bahan baku. Barang setengah jadi dan atau barang dagangan, serta masih memiliki tagihan-tagihan kepada pihak ketiga.

Bank Mandiri telah memberikan saran-saran dan solusi terhadap kendala usaha yang terjadi pada debitur sehingga nantinya kredit yang tertunggak akan lancar kembali dengan mempertimbangkan keadaan industri seperti permasalahan struktural dalam industri mempengaruhi risiko kredit secara keseluruhan, misalnya pendapatan rendah, biaya tinggi dan persaingan sangat tinggi melalui Management Assistancy ${ }^{10}$.

Setelah dilakukan upaya tersebut ternyata usaha debitur tidak mengalami kemajuan dan tetap mengalami kesulitan dalam pembayaran kreditnya diikuti dengan memberikan surat peringatan terhadap debitur yang isinya untuk segera menyelesaikan kewajiban tunggakan pokok dan/atau bunga kredit yang telah jatuh tempo/tertunggak. Ternyata debitur masih tidak bisa memenuhi kewajibannya sehingga kategori kreditnya digolongkan macet. ${ }^{11}$

Melelang agunan debitur yang kreditnya macet menjadi pilihan perbankan untuk menutupi utang debitur kepada Bank, hal ini menjadi salah satu cara untuk menekan angka Non Performing Loan (NPL) atau kredit macet. Pelelangan yang dilakukan oleh perbankan akan melibatkan Kantor Pelayanan Kekayaan Negara dan Lelang (KPKNL). Sebelum proses lelang terjadi, perbankan akan berkoordinasi dengan KPKNL untuk selanjutnya diumumkan akan adanya pelelangan itu di media massa. Di KPKNL Jambi dalam setahun ada sekitar 200 permintaan lelang, dari jumlah itu 50 persennya berasal dari perbankan termasuk di antaranya Bank Swasta, tapi tidak semua agunan yang dilelang laku. ${ }^{12}$

PT. Bank Mandiri (Persero) Tbk mengambil langkah penyelesaian kredit macet melalui Agunan Yang Diambil Alih (AYDA) akibat tidak terjualnya agunan Nyonya S di pelelangan karena tidak tercapai harga limit yang ditentukan. Penyelesaian kredit macet melalui AYDA itu sendiri tidak dilakukan diawal proses kredit macet atau dicantumkan dalam perjanjian kredit maupun dalam Akta Pembebanan Hak Tanggungan (APHT) penyelesaian ini disepakati kemudian antara PT. Bank Mandiri (Persero) Tbk dengan debitur setelah dilakukan pelelangan dan aset debitur tidak laku terjual. Pelaksanaan AYDA diawali dengan adanya kesepakatan antara kreditur dengan debitur untuk dilakukannya AYDA. AYDA itu sendiri istilah yang digunakan dalam perbankan, pada dasarnya konsepnya seperti penjualan di bawah tangan antara kreditur dengan debitur. ${ }^{13}$

Bank Mandiri mengajukan permohonan lelang secara tertulis ke Kantor Pelayanan Kekayaan Negara dan Lelang (KPKNL), setelah dilakukan pelelangan terhadap agunan dan tidak terjual, maka barulah Bank Mandiri dapat mengambil langkah penyelesaian kredit macet Nyonya $\mathrm{S}$ melalui pengambilalihan asset debitur. Bank akan memusyawarahkan hal ini dengan debitur, apabila disepakati maka pihak bank akan melaksanakan pengambil alihan agunan, kesepakatan dapat dituangkan dalam perjanjian tertulis atau dalam berita acara penyelesaian kredit yang ditandatangani oleh debitur diatas materai, hal ini dibutuhkan sebagai

${ }^{10}$ Management Assistancy yaitu bantuan konsultasi dan manajemen profesional yang diberikan Bank Mandiri kepada debitur yang masih mempunyai itikad baik untuk melunasi kewajibannya.

${ }^{11}$ Berdasarkan hasil wawancara dengan Bapak Yudi Iswahyudi selaku Team Leader Business Banking Center (BBC) PT. Bank Mandiri (Persero) Tbk Cabang Jambi, tanggal 2 Desember 2013

12 Berdasarkan hasil wawancara dengan Ibu Istiqomah Handayani selaku Kepala Seksi Kepatuhan Internal KPKNL Jambi, tanggal 9 Desember 2013

${ }^{13}$ Berdasarkan hasil wawancara dengan Bapak Yudi Iswahyudi selaku Team Leader Business Banking Center (BBC) PT. Bank Mandiri (Persero) Tbk Cabang Jambi, tanggal 2 Desember 2013 
bentuk ketersediaan dan kesukarelaan debitur dalam penyerahan agunannya, walaupun pada prakteknya pengambil alihan dilakukan dengan mekanisme penjualan di bawah tangan antara debitur/ pemilik agunan dengan Bank sebagai pembeli.

Setelah adanya kesepakatan, Bank Mandiri yang melakukan pengambilalihan asset debitur untuk jangka waktu sementara, maksimal 1 (satu) tahun sebelum dijual kepada pihak lain membuat akta de command, kuasa jual diikuti dengan Perjanjian Perikatan Jual Beli (PPJB) oleh Notaris, surat pernyataan dari debitur dan dokumen-dokumen pengikatan lainnya yang diperlukan. Penyelesaian kredit macet melalui pengambilalihan asset debitur dengan surat kuasa jual dan PPJB tersebut dilakukan oleh bank melalui karyawan yang dikuasakan. Setelah dilakukan pengambilalihan maka Bank Mandiri mengambil pelunasan piutangnya terlebih dahulu daripada kreditur yang lain jika ada beberapa kreditur. Setelah mengambil pelunasan hutang pokok beserta bunga dan biaya-biaya lainnya, jika ada sisa penjualan maka sesuai ketentuan dalam perjanjian pokoknya yaitu perjanjian kredit, Bank hanya bisa mengambil pelunasan sebesar outstanding/kewajiban hutangnya, dan sisa hasil penjualan menjadi hak debitur, dasar pengembalian sisa hasil penjualan tersebut adalah surat pemberitahuan dari Bank kepada debitur.

Asas Lex Superior Derogat Legi Inferiori menyatakan bahwa peraturan yang lebih rendah tidak boleh bertentangan dengan peraturan yang lebih tinggi. Peraturan yang lebih tinggi akan mengesampingkan peraturan yang lebih rendah. Ketentuan Pasal 12 Undang-Undang Hak Tanggungan (UUHT) bertentangan dengan ketentuan AYDA dalam Pasal 1 ayat (15) Peraturan Bank Indonesia Nomor 14/15/PBI/2012 tentang Penilaian Kualitas Aset Bank Umum, maka seharusnya hal tersebut bertentangan dengan Asas Lex Superior Derogat Legi Inferiori.

Bank dalam prakteknya dapat melaksanakan AYDA sebagai langkah penyelesaian kredit macet, untuk itu dalam kasus AYDA asas tersebut tidak sepenuhnya bertentangan, karena sebelum melakukan AYDA, Bank terlebih dahulu melakukan eksekusi obyek jaminan Hak Tanggungan melalui pelelangan umum sesuai ketentuan Pasal 6 UUHT, dalam hal obyek lelang tidak laku terjual, maka barulah Bank mengambil langkah penyelesaian kredit macet melalui AYDA atas dasar kesepakatan. Bank mengambil langkah AYDA dengan tujuan untuk likuiditas Bank, terkait pelunasan hutang debitur kepada Bank. Likuiditas suatu Bank berhubungan erat dengan masalah kemampuan suatu Bank untuk memenuhi kewajiban finansialnya. Bank harus mempunyai aktiva lancar yang jumlahnya harus lebih besar dari jumlah kewajiban-kewajiban yang harus segera dipenuhi yang berupa hutang-hutang. Semakin besar jumlah aktiva lancar yang dimiliki oleh suatu Bank dibandingkan dengan hutang lancar, maka semakin besar tingkat likuiditas Bank tersebut, dan sebaliknya apabila jumlah aktiva lancar lebih kecil daripada hutang lancar, berarti Bank tersebut berada dalam likuid.

\section{Peran Pejabat Pembuat Akta Tanah Dalam Pembuatan Akta Terhadap Obyek Jaminan Yang Diambil Alih oleh PT. Bank Mandiri (Persero) Tbk Cabang Jambi.}

Kehadiran Notaris/PPAT adalah untuk melayani kepentingan masyarakat yang membutuhkan aktaakta otentik maupun surat-surat lain yang menjadi kewenangannya. Notaris/PPAT dapat dikatakan profesional jika dilengkapi dengan berbagai keilmuan yang mumpuni yang dapat diterapkan dalam praktik. Bagaimana mengolah nilai-nilai atau ketentuan-ketentuan yang abstrak menjadi suatu bentuk yang tertulis (akta) sesuai yang dikehendaki oleh para pihak.

Ada dua (2) cara dalam menjalankan proses AYDA, yaitu pertama melalui pelelangan dilanjutkan dengan membuat risalah lelang yang merupakan kewenangan Notaris, kemudian yang kedua melalui penyerahan secara sukarela dari debitur kepada kreditur dengan membuat Perjanjian Pengikatan Jual Beli (PPJB) dan Kuasa untuk menjual yang merupakan kewenangan Notaris kemudian dilanjutkan dengan pembuatan Akta Jual Beli (AJB) yang merupakan kewenangan PPAT.

AYDA melalui penyerahan secara sukarela, maka dengan cara membuat kuasa menjual diikuti dengan Perjanjian Perikatan Jual Beli (PPJB), surat kuasa jual dari debitur dan dokumen-dokumen pengikatan lainnya yang diperlukan. Penyelesaian kredit macet melalui pengambilalihan asset debitur dengan surat kuasa menjual dan PPJB tersebut dilakukan oleh bank melalui karyawan yang dikuasakan.

Menurut Bapak Firman Gusri menambahkan dengan dibuatnya PPJB antara Bank dengan Debitur dengan pertimbangan bahwa Bank tidak diperbolehkan untuk memiliki agunan tersebut dan berkewajiban dalam jangka waktu satu tahun sejak diambilalih agunan harus segera dicairkan. Sehingga ketika Bank 
maupun debitur menemukan pembeli akhir, PPJB akan dilanjutkan dengan pembuatan AJB. PPJB dibuat untuk menangguhkan biaya-biaya yang timbul akibat peralihan hak atas tanah dan bangunan seperti Biaya pajak pembeli 5\% (BPHTB), Biaya pajak penjual 5\%, biaya balik nama. Hambatan terjadi ketika telah dilakukan pengambilalihan obyek jaminan Hak Tanggungan oleh kreditur adalah tidak diketahuinya keberadaan debitur atau pemilik obyek jaminan Hak Tanggungan, sedangkan apabila telah didapat pembeli baru, maka pemilik obyek jaminan Hak Tanggungan harus ikut dalam penandatanganan AJB. ${ }^{14}$

Tujuan penyelesaian kredit macet melalui pengambilalihan aset debitur (AYDA) tersebut adalah untuk mengurangi kredit bermasalah, karena dengan diambil alihnya aset tersebut, maka hutang debitur secara langsung dianggap lunas, karena menumpuknya kredit bermasalah akan berpengaruh terhadap tingkat kesehatan bank. Hal tersebut diperbolehkan dan diatur oleh UU Perbankan dengan syarat pengambilalihan dilakukan untuk mencairkan aset tersebut kembali dalam jangka waktu paling lama 1 (satu) tahun untuk bank umum. Dalam pengambilalihan agunan diperlukan alas hak yang berupa akta jual beli agunan antara kreditur sebagai pembeli dan debitur sebagai penjual. Akta Jual Beli (AJB) merupakan alas hak atau alas hukum untuk memindahkan hak milik debitur berupa agunan kepada kreditur. Bagi agunan barang tidak bergerak berupa tanah dan bangunan yang melekat diatasnya maka akta jual beli dibuat oleh Pejabat Pembuat Akta Tanah (PPAT).

Perjanjian Kredit antara kreditur dengan debitur menjadi hapus karna dibuatnya AJB tersebut, hal ini dinamakan Novasi Obyektif. Novasi adalah suatu persetujuan yang menyebabkan hapusnya suatu perikatan dan pada saat yang bersamaan timbul perikatan lainnya yang ditempatkan sebagai pengganti perikatan semula. ${ }^{15}$ Novasi Obyektif yaitu perikatan yang telah ada diganti dengan perikatan lain. Kreditur dan debitur mengadakan perjanjian baru, dengan mana perjanjian lama dihapuskan, dalam kasus AYDA di atas, Perjanjian Kredit antara kreditur dengan debitur hapus karna adanya Akta Jual Beli (AJB).

\section{SIMPULAN}

Berdasarkan hasil penelitian dan pembahasan yang telah diuraikan sebelumnya, maka dapat diambil kesimpulan sebagai berikut:

1. Pengambilalihan Obyek Jaminan Hak Tanggungan Milik Debitur yang Mengalami Kredit Macet oleh PT. Bank Mandiri (Persero) Tbk Cabang Jambi dilakukan manakala telah dilakukan eksekusi melalui pelelangan umum tetapi obyek jaminan Hak Tanggungan tidak laku terjual, Bank memusyawarahkan pengambilalihan ini dengan debitur, setelah disepakati maka pihak Bank akan melaksanakan pengambilalihan agunan, kesepakatan dituangkan dalam perjanjian tertulis, walaupun pada prakteknya pengambilalihan dilakukan dengan mekanisme penjualan di bawah tangan antara debitur/ pemilik agunan dengan Bank sebagai pembeli. Bank melakukan pengambilalihan asset debitur untuk jangka waktu sementara, maksimal 1 (satu) tahun sebelum dijual kepada pihak lain, melalui Notaris membuat akta de command, kuasa jual diikuti dengan Perjanjian Perikatan Jual Beli (PPJB). Penyelesaian kredit macet melalui pengambilalihan asset debitur dengan surat kuasa jual dan PPJB tersebut dilakukan oleh Bank melalui karyawan yang dikuasakan.

2. Peran Pejabat Pembuat Akta Tanah (PPAT) dalam pembuatan akta terhadap obyek jaminan yang diambil alih oleh PT. Bank Mandiri (Persero) Tbk Cabang Jambi yaitu membuat Akta Jual Beli (AJB), dimana AJB merupakan alas hak yang sah terhadap beralihnya hak atas tanah. AJB dibuat ketika ada pembeli baru terhadap agunan yang diambil alih oleh Bank. Bank melakukan pengambilalihan asset debitur untuk jangka waktu sementara, maksimal 1 (satu) tahun sebelum dijual kepada pihak lain dengan cara membuat kuasa menjual diikuti dengan Perjanjian Perikatan Jual Beli (PPJB) yang dibuat oleh Notaris, Notaris berwenang membuat PPJB dan Kuasa Menjual. Penyelesaian kredit macet melalui pengambilalihan as set debitur dengan surat kuasa jual dan PPJB tersebut dilakukan oleh bank melalui karyawan yang dikuasakan, ketika pembeli baru sudah ditemukan maka dilanjutkan dengan membuat Akta Jual Beli (AJB) dihadapan PPAT setempat. PPAT dalam hal ini berwenang membut Akta Jual Beli (AJB). AJB

${ }^{14}$ Berdasarkan hasil wawancara dengan Bapak Firman Gusri, SH., MKn, Notaris/PPAT Kota Jambi tanggal 5 Desember 2013

\footnotetext{
${ }^{15}$ Wawan Muhwan Hariri, Hukum Perikatan, Pustaka Setia, Bandung, 2011, hlm.218
} 
dibuat atas dasar Perjanjian Kredit antara kreditur dan debitur menjadi hapus, hapusnya Perjanjian Kreditkarena AJB tersebutdinamakanNovasiObyektif.

\section{DAFTAR PUSTAKA}

\section{Buku}

Subekti, 1995, Aneka Perjanjian, PT. Citra Aditya Bakti, Bandung. 2002, Hukum Perjanjian, Intermasa, Jakarta.

Hariri, Wawan Muhwan, 2011, Hukum Perikatan, Pustaka Setia, Bandung.

Muljadi, Kartini dan Gunawan Widjaja, 2007, Seri Hukum Harta Kekayaan: Hak Istimewa,Gadai, dan Hipotek, Kencana, Jakarta.

Poesoko, Herowati, 2008, Parate Executie Obyek Hak Tanggungan, Laksbang Pressindo, Yogyakarta.

Usman, Rachmadi, 2008, Hukum Jaminan Keperdataan, Sinar Grafika, Jakarta.

\section{Peraturan}

Undang - Undang Nomor 5 Tahun 1960 Tentang Peraturan Dasar Pokok - Pokok Agraria Lembaran Negara Republik Indonesia Tahun 1960 Nomor 104.

Undang - Undang Nomor 4 Tahun 1996 Tentang Hak Tanggungan Lembaran Negara Republik Indonesia Tahun 1996 Nomor 42.

Undang - Undang Nomor 10 Tahun 1998 tentang perubahan atas Undang-Undang No.7 Tahun 1992 tentang Perbankan Lembaran Negara Republik Indonesia Tahun 1998 Nomor 182.

Peraturan Bank Indonesia Nomor 6/25/PBI/2004 tentang Rencana Bisnis Bank Umum.

Peraturan Bank Indonesia Nomor 14/15/PBI/2012 tentang Penilaian Kualitas Aset Bank Umum. 